$\xi=$

\title{
Financial Performance Analysis Before and After the Decline in Oil Production: Case Study in Indonesian Oil and Gas Industry
}

\author{
Wiwiek Mardawiyah Daryanto ${ }^{1}$, Dety Nurfadilah $^{2}$ \\ ${ }^{1}$ Sekolah Tingi Manajemen IPMI, Jakarta 12750, Indonesia \\ ${ }^{2}$ Faculty of Economics, Universitas Krisnadwipayana, Jakarta 13077, Indonesia \\ *Corresponding author E-mail: wiwiek.daryanto@ipmi.ac.id
}

\begin{abstract}
Indonesia's oil and gas industry is the huge contributor to government export revenues and foreign exchange and contributes a substantial amount to state revenue. However, the total of oil production declined around 4,41\% per year since 2007, and the sharpest decline was in 2013. This situation gives impact to the performance of oil and gas industry, especially government revenues. Therefore, the purpose of this study is to measure the financial performance of Oil and Gas Industry and to examine the significance differences between the financial performance before and after the decline in oil and gas production. The data were collected from financial report and the period was divided into two periods, before the decline in production $(2011$ - 2012) and after the decline in production (2014 - 2015). Paired sample t-test and financial ratio analysis (FRA) were used to analyzed the data. The finding shows that the largest oil and gas company in Indonesia is still in good financial condition, although it gained loss. In addition, current ratio and return on equity had significance difference during the period of before and after a decline in oil and gas production. The authors believe that the findings will be helpful for managers who continuously attempt to explore opportunities to provide a higher return.
\end{abstract}

Keywords: Financial performance; oil price; solvency; profitability; SEOs.

\section{Introduction}

In recent years, oil and gas industry has become the vital part of the economics of Indonesia and Global market. This industry gives huge contribution in many ways, including investment, job creation, regional growth, and oil export revenue, taxation, and energy security. It even played a huge role in human life. For examples, petroleum can be used to make plastic, water bottle, and roads. It can keep our engine run smoothly and gas can be used to cook food.

In the case of oil price, Oil and Gas industry has experienced dramatic volatility, both Indonesia and Globally (1-5) supported that the oil price has been volatile since its first oil crisis in 1973. According to PWC in year 2016, the amount of oil price in the global market declined sharply from US $\$ 145$ per barrel in the mid of 2008 to approximately US $\$ 40$ per barrel at the end of 2008 . Then oil price was an increase at US\$ 77,11 per barrels in 2010 and a further increased at US $\$ 91,39$ per barrels in 2011 as per Energy today in year 2015. However, the amount of oil price fell slightly at US\$88,95 per barrels in 2012 and a further fell at US\$ 49,93 per barrels in May 2016. On the other hand, the oil price in Indonesia is not in line with the changes of oil price in global. In 2008, the amount of oil price was lower than the crude oil price in global which is US\$96,13 per barrels and then it fell down to US\$61,58 per barrels in 2009 as reported by Indonesia Crude Price in year 2009. Next, there was a significant increase at US\$ 79,4 per barrels in 2010 and a further increased to 112,73 per barrels. However, it falls down to US\$ 49,46 per barrels in 2016 as explained by Ministry of Energy and Mineral Resources of
Republic of Indonesia in year 2016. The volatility of oil price has been affected by the limited production and high demand.

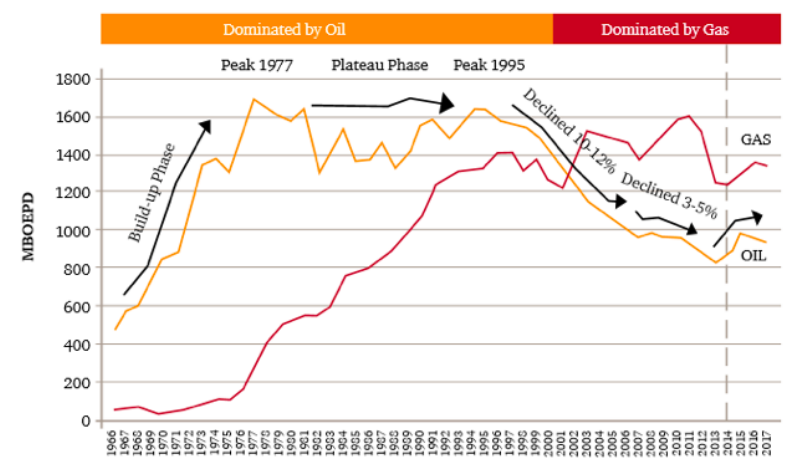

Source: SKK Migas Annual Report 2014

Fig. 1: Performance of crude oil and gas

Figure 1 gives information about the performance of crude oil and gas production in Indonesia between 1966 and 2017. Overalls, the amount of oil and gas production fluctuated. The highest amount of oil and gas production was in 1977 and 2011 respectively. The lowest amount of oil and gas production is from 2013 to 2014. In crude oil production, there was a sharp increase from just over 400 MBOEPD in 1966 to approximately 1677 MBOEPD in 1977, and then it declined dramatically to 825 MBOEPD production, it increased dramatically from approximately 70 MBOEPD in 1966 to just over 800 MBOEPD in 2011, however, it decreased to 1225 MMSCFD in 2013 and it is expected to increase to 1375 MMSCFD in 2017. In other meaning, Oil production in Indonesia has experienced a sharp decline about $4,41 \%$ per year. 
This unpredictable situation has affected the business sectors in many ways. According to Rohimat \& Sutarman (6), there are many companies and countries that rely on oil revenue and end up falling and collapse. For example, the biggest company of oil and gas services in the world, Schlumberger, cut off their worker around 34,000 staffs in 2014 and 10,000 staffs in 2016. Then, Petronas Malaysia will dismiss 1,000 employees in 2016 because they want to cut expenses around $\$ 12$ billion (7). In Indonesia, Chevron would terminate their contracts in East Kalimantan after 50 years of operation and dismiss around 1,500 employees due to decline in the efficiency (8). In addition to that, Oil and Gas industry still remains the main sources of state revenue, although the volatility of oil price gives a huge impact to the economy sectors. According to Frecka \& Lee (9), firms should measure the financial ratio and adjust the performance based on industry norms. Most studies on financial performance have focused on bank, retail and manufacturing, hospital, construction and SME industry (10-13). The present study is focusing on oil and gas industry. It is covering one of the biggest Oil and Gas Company in Indonesia in the period $2011-2015$. The purpose of this study is to measure the level of financial performance of Oil and Gas industry in Indonesia using financial ratio analysis and to examine the differences between the performance of oil and gas in the period of before and after the decline in crude oil and gas production. The outcome of this study will facilitate the student and academicians to assess the financial performance of the company and to make learning more practical and understood. This study also will be beneficial for managers to evaluate the performance of their company before making decisions.

This study is organized into seven sections. Section one captures the introduction, section two highlight the performance of Indonesia's oil and gas industry, section three highlight the literature review about previous researchers, section four discuss the methodology, section five discuss the finding and analysis, section six highlights the implication and section seven captures the conclusion.

\section{Development of Oil and Gas Industry in Indonesia}

In Indonesia, the existence of Oil and Gas industry has begun since 1871 or more than 130 years ago with their first oil production in 1885 in North Sumatera. After the independence in 1950, the government of Republic Indonesia began to inventory the sources of state income which include the business from oil and gas. But then, there were conflicts between one company and other company who competing to control these fields. It looked unmanageable and filled with conflict. In 1957, PT PERMINA restructured into PN PERMINA and established PERTAMINA. It followed the government policy that the party entitled to conduct oil and gas exploration in Indonesia is the government.

In 1962, Indonesia joined The Organization of the Petroleum Exporting Countries (OPEC) with Iran, Iraq, Kuwait, Saudi Arabia, Venezuela, Qatar, Libya, United Arab Emirates, Algeria, Nigeria, Ecuador, Angola, and Gabon as explained on OPEC website, in year 2016. This collaboration has helped them to establish a good research, develop the organization's international standing, and set good and fair prices for petroleum producers. To strengthen the operation of this company, the government issued Law No. 8 in 1971, where it set the role of PERTAMINA as the only stateowned company who implement and exploit the oil and gas. It began from manage and produce oil and gas from the oil fields in the whole of Indonesia, processed into various products and provide the needs of fuel oil \& gas throughout Indonesia.

In 2001, Government implements the Act No. 22/2001. After the implementation, the position of Pertamina is equal with other oil companies. On 17 September 2003, PERTAMINA changed into PT PERTAMINA (Persero) under PP 31/2003. The Act, among others, also requires the separation between the oil and gas busi- ness activities in the downstream and upstream. Furthermore, on July 20, 2006, PT PERTAMINA launched a program about the transformation of the company with two major themes namely fundamental and businesses. To further solidify the transformation program, on December 10, 2007, PT PERTAMINA changed the company's vision became, "To be a World Class National Oil Company". Responding to the prevailing global development, PERTAMINA is seeking to expand the field of oil and gas efforts toward the development of new and renewable energy. However, Indonesia began to import oil in 2004 due to lower oil production and high demand of consumption. Indonesia suspended its membership in 2008 due to oil and financial crisis. After seven years of absence, Indonesia decided to return to OPEC in 2015.

Table 1: Key Indicator

\begin{tabular}{|c|c|c|c|c|c|c|c|c|c|}
\hline Indicator & 2007 & 2008 & 2009 & 2010 & 2011 & 2012 & 2013 & 2014 & 2015 \\
\hline \multicolumn{10}{|l|}{ Reserves } \\
\hline $\begin{array}{l}\text { Oil (Million } \\
\text { Barrels) }\end{array}$ & 8,400 & 8,220 & 8,000 & 7,760 & 7,730 & 7,410 & 7,550 & 7,370 & $7,370^{*}$ \\
\hline Proven & 3,990 & 3,750 & 4,300 & 4,230 & 4,040 & 3,740 & 3,690 & 3,620 & 3,692 \\
\hline Potential & 4,410 & 4,470 & 3,700 & 3,530 & 3,690 & 3,670 & 3,860 & 3,750 & $3,750^{*}$ \\
\hline **Gas (TCF) & 165.00 & 170.10 & 159.63 & 157.14 & 152.89 & 150.70 & 150.39 & 149.30 & $149.30^{*}$ \\
\hline Proven & 106.00 & 112.50 & 107.34 & 108.40 & 104.71 & 103.35 & 101.54 & 100.26 & 103.35 \\
\hline Potential & 59.00 & 57.60 & 52.29 & 48.74 & 48.18 & 47.35 & 48.85 & 49.04 & 49.04* \\
\hline \multicolumn{10}{|l|}{ Production } \\
\hline $\begin{array}{ll}* * * \text { Crude } & \text { Oil } \\
\text { (MBOPD) } & \end{array}$ & 972 & 1,006 & 994 & 1,003 & 952 & 918 & 825 & 789 & 779 \\
\hline $\begin{array}{l}\text { *** Natural gas } \\
\text { (MMSCFD) }\end{array}$ & 7,283 & 7,460 & 7,962 & 8,857 & 8,415 & 7,110 & 6,826 & 8,218 & 8,102 \\
\hline $\begin{array}{l}\text { New contract } \\
\text { signed }\end{array}$ & 28 & 34 & 34 & 21 & 31 & 39 & 14 & 7 & 12 \\
\hline $\begin{array}{l}\text { Source: } \\
* 2007-201 \\
* 2015 \text { Oil } \\
* * 2007-20 \\
* * 2015 \mathrm{Ga} \\
\text { available } \\
* * * 2007-2 \\
2014 \text { Crude } \\
{ }^{* *} \text { 2 } 2015 \mathrm{C} \\
{ }^{* *} 2015 \mathrm{~N}\end{array}$ & $\begin{array}{l}\text { il and } \mathrm{N} \\
\text { ie oil p. }\end{array}$ & tion: 1 & ry of $\mathrm{F}$ & s: ESDM & dgget & $\begin{array}{l}2013 \mathrm{a} \\
\text { ation) }\end{array}$ & $\begin{array}{l}\text { orld } \\
014\end{array}$ & data no & \\
\hline
\end{tabular}

According to Cooper (14), Indonesia is on top 10 of world's oil producers with the total reserve around 2,900 billion cubic feet. Indonesia's reserves are on $14^{\text {th }}$ rank in the world. Based on table 1 , the number of crude oil production decreased by 972 thousand barrels of oil equivalents per day in 2007 to 779 thousand barrels of oil equivalents per day in 2015 , while the number of natural oil production increased from 7,238 thousand barrels of oil equivalents per day in 2007 to 8,102 thousand barrels of oil equivalents per day in 2015 .

Table 2: Oil and Gas Contribution to State Revenue

\begin{tabular}{|r|r|r|r|}
\hline \multicolumn{1}{|c|}{ Year } & State Revenue & Oil/Gas Revenue & \% of contribution \\
\hline \multicolumn{3}{|c|}{ Rp Trilion } \\
\hline 2004 & 403 & 85 & $21.09 \%$ \\
\hline 2005 & 494 & 104 & $21.05 \%$ \\
\hline 2006 & 636 & 158 & $24.84 \%$ \\
\hline 2007 & 706 & 125 & $17.71 \%$ \\
\hline 2008 & 979 & 212 & $21.65 \%$ \\
\hline 2009 & 847 & 126 & $14.88 \%$ \\
\hline 2010 & 992 & 153 & $15.42 \%$ \\
\hline 2011 & 1,205 & 193 & $16.02 \%$ \\
\hline 2012 & 1,338 & 205.8 & $15.38 \%$ \\
\hline 2013 & 1,438 & 180.6 & $12.56 \%$ \\
\hline 2014 & 1,538 & 216.9 & $14.11 \%$ \\
\hline 2015 & 1,758 & 78.4 & $4.46 \%$ \\
\hline $2016 *$ & 1,830 & 62.88 & $3.44 \%$ \\
\hline
\end{tabular}
Source: Ministry of Finance $(2016)$

Based on table 2, state revenue has been increased, while the oil and gas revenue and the percentage of contribution have fluctuated between 2014 and 2016. In 2004, the amount of state revenue was Rp. 403 trillion and the amount of oil and gas revenue was Rp. 85 trillion with $21.09 \%$ of contribution to the state. Those amounts increased dramatically to Rp. 636 trillion and Rp. 158 trillion respectively in 2006 . However, there was a sharp decline in the total amount of oil and gas revenue at Rp. 125 trillion 
with $17.71 \%$ of contribution in 2006 , although the amount of state revenue increased to Rp. 706 trillion. Moreover, the amount of state revenue and oil and gas revenue increased dramatically to $\mathrm{Rp}$. 1,538 trillion and Rp. 216.9 trillion with $14.11 \%$ of contribution in 2014 respectively. However, there was a dramatic decline in oil and gas revenue to Rp. 78 trillion in 2015 with a budgeted decrease to Rp. 63 trillion in 2016. In addition, the percentage of contribution fell from $14.11 \%$ in 2014 to $4.46 \%$ in 2015 , and a further decline to $3.44 \%$ in 2016 , although the amount of state revenue is expected to increase to Rp. 1,830 trillion. It is expected to decline to $3 \%$ for the next period (Price Water House Cooper, 2016).

\section{Previous Research on Financial Perfor- mance}

According to Charliepaul et al. (15), the financial ratio is a good evaluation method to measure the company performances. The company usually uses this method to compare their performance with other competitors. There are two methods to measure the financial performances which are accounting and market measurement. There are many researchers who prefer to use accounting measurement $(16,17)$, rather than market measurement $(18,19)$, and some of them adopt both methods (20). There are few differences between accounting and market measurement method. In accounting, the company uses the historical aspects to measure their financial performance (21) and it contains a bias which leads to managerial manipulation. On the other hand, the market measurement method is straight forward, focus on performance and represent the ability of a company to generate future income (20). There have been a large number of empirical studies on the financial ratio in different industries around the world $(22,23)$. However, there are limited resources which evaluate the financial performance of Oil and Gas Company in Indonesia. According to Tarawneh (23), the financial ratio analysis (FRA) has been applied in Banking industry to examine, evaluate, and ranked based on their performance. Based on the study in Oman Commercial Banks, financial performance has a relationship with asset management, size, and operational efficiency. (24) investigated the financial performance in four major Oil and Gas Company and found that three of them have a high level of satisfactory and Exxon Mobil was the outstanding one. According to (25), there is significance different in the performance of oil and gas industry in Indonesia between ROA, ROE, current ratio, and quick ratio in the period of before and after the global crisis.

\section{Research Model}

Based on figure 2, this research model adapted from the previous study by (25). It describes the process of measuring financial performance and examines the differences between the performance of oil and gas industry before and after the decline in oil and gas production. It expands the knowledge with more practical experience.

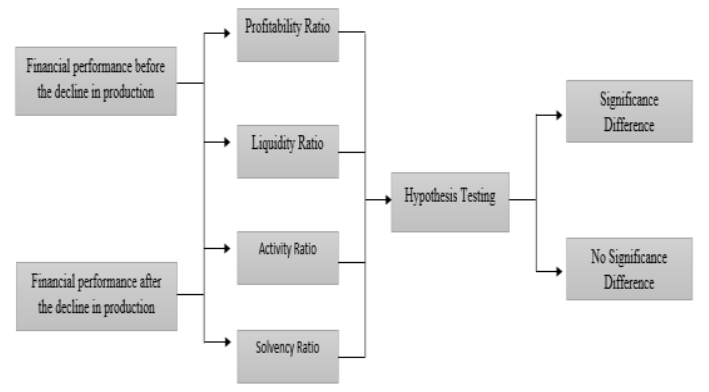

Fig. 2: Research model

\section{Hypothesis}

- H1: Using cash ratio, there is a significance difference in financial performance before and after the decline in oil and gas production.

- H2: Using current ratio, there is a significance difference in financial performance before and after the decline in oil and gas production.

- H3: Using a total of equity to total asset ratio, there is significance in financial performance difference before and after the decline in oil and gas production.

- H4: Using return on equity ratio, there is a significance difference in financial performance before and after the decline in oil and gas production.

- H5: Using return on investment ratio, there is a significance difference in financial performance before and after the decline in oil and gas production.

- H6: Using investment turnover ratio, there is a significance difference in financial performance before and after the decline in oil and gas production.

- H7: Using total asset turnover, there is a significance difference in financial performance before and after the decline in oil and gas production.

- H8: Using collection period ratio, there is a significance difference in financial performance before and after the decline in oil and gas production.

\section{Methodology}

To accomplish this study, descriptive financial ratio analysis used to measure, describe and analyze the financial performance of Oil and Gas Company in Indonesia during the period of $2011-2015$ and Paired sample t-test is used to examine the significance differences in the period of before $(2011-2012)$ and after declining in crude oil production $(2014-2015)$. Paired sample t-test is a statistical technique to use in before-after studies and use to compare two population means. It has been used many times in the previous study in workers' productivity, medical, business, and much more $(26,27)$. PT PERTAMINA was selected because it is the first oil and gas company in Indonesia with their extensive experience in the industry. In this research, data were collected from Annual Report (audited) from 2011 to 2015. The variables are shown in table 2 . It consists of profitability ratio, liquidity ratio, activity ratio, and solvency ratio.

\section{Result and Discussion}

\subsection{Profitability Performance}

The line chart below gives information about the percentage of return on equity (ROE) and return on investment (ROI) in PTPERTAMINA between 2011 and 2015. Overall, the percentage of ROI increased sharply and there was a sharp decrease in the percentage of ROE. The highest percentage was ROI and the lowest percentage was ROE. Between 2011 and 2012, the percentage of ROI was decreased slightly from $16.57 \%$ to $14.59 \%$. It is caused by the declined of oil prices. Then it increased to $21.75 \%$ in 2013 and a further increase to $25.31 \%$ in 2015 . In ROE, there was a significant decrease from $18.11 \%$ in 2011 to $7.41 \%$ in 2015 . The huge declined happened in 2014 because the demand was high, but the supply was low. So, the government imported more oil from 228.81 million barrel in 2013 to 243.56 million barrel in 2014 with the aims to fulfill the need of society as explained by Pertamina Annual Report in year 2015). 


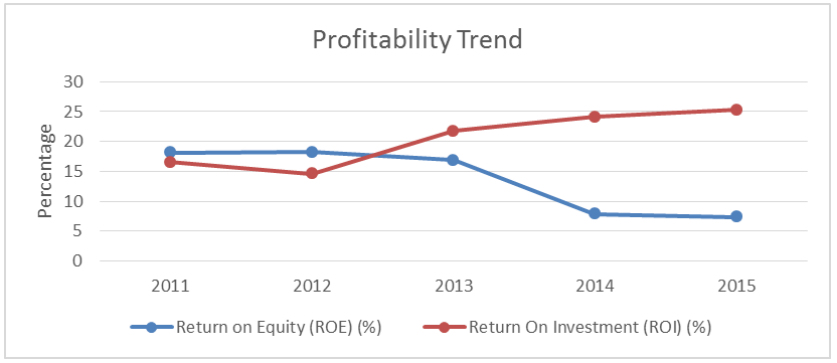

Fig. 3: Profitability Trend

\subsection{Liquidity Performance}

The graph below shows the percentage of cash ratio and a current ratio of PT. PERTAMINA from 2011 to 2015. Overall, there was a slight increase in the percentage of cash ratio and current ratio. The highest percentage was current ratio and the lowest was cash ratio. The current ratio is the general indicator to measure the liquidity of the company. In the horizontal analysis, the average current ratio for the past five years was $151.61 \%$ which means that $\mathrm{Rp} 1,-$ of current liability were to be guaranteed by $\mathrm{Rp} 1.5161$ of a current asset. Between 2011 and 2015, the percentage of current ratio rose slightly from $138.09 \%$ to $157.70 \%$ and then it decreased to $145.5 \%$ in 2013 . Then, there was a slight increase to approximately $167.67 \%$ in 2015 . In cash ratio, the percentage increased slightly from $27.38 \%$ in 2011 to $39.97 \%$ in 2015 . The average of cash ratio for the last five years was $31.784 \%$. It indicates that the number of current liabilities was guaranteed by cash. PT. PER TAMINA can optimally manage its working capital within safe limits. So, it does not have short-term financial problems or the company in a liquid condition.

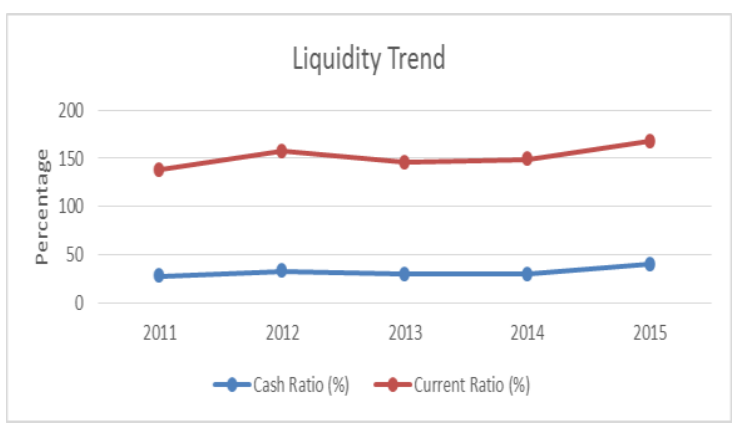

Fig. 4: Liquidity Trend

\subsection{Activity Performance}

The line chart below gives information about the percentage of inventory turnover and total assets turnover and the number of collection period from PT. PERTAMINA between 2011 and 2015 Overall, there was a slight decrease in the number of those three ratios. In inventory turnover (ITO), the percentage decreased slightly from $42.43 \%$ in 2011 to $39.09 \%$ in 2014 and there was a slight decrease in the percentage of total assets turnover (TATO) from 247.48 in $2014 \% 118.19 \%$ in 2014 . In collection period (CP), the number decreased slightly from 19 days in 2011 to 22 days in 2014. We can conclude that those three ratios were in good condition and the management of assets ran efficiently.

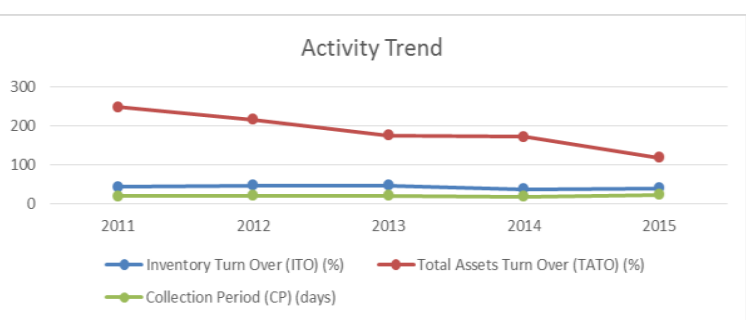

Fig. 5: Activity Trend

\subsection{Solvency Performance}

The graph below shows the percentage of the total of equity to total asset (TETA) ratio between 2011 and 2015. Overalls, there was a dramatic increase. Between 2011 and 2013, the percentage decreased slightly from $38.03 \%$ to $36.69 \%$ and then it increased to $42.78 \%$ in 2015 . In the long term, PT. PERTAMINA rated insolvent because the average ratio of total equity to a total asset for the last 5 years was only $38354 \%$, where the general standard was $50 \%$. It shows that the risks of the company were higher unless the company can achieve high profit.

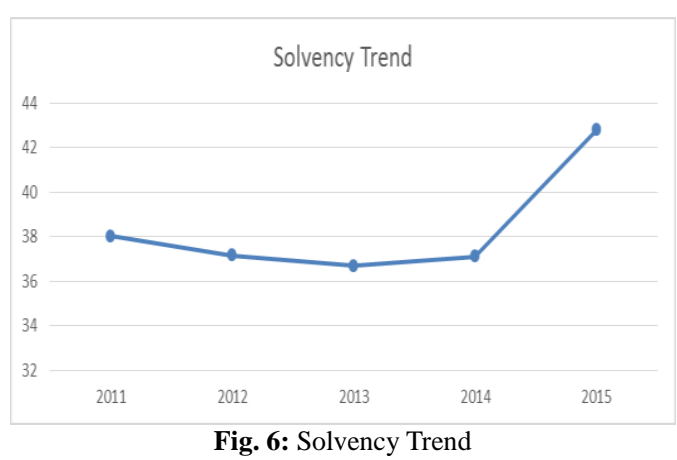

\subsection{Hypothesis Testing}

Table 3 gives information about the result from paired sample ttest. Overall, two hypothesis are accepted and six hypothesis are rejected. The result found that current ratio has statistically significance difference between the mean before and after the decline in oil and gas production with the $\mathrm{P}$-value $\leq \alpha(0.021<0.05)$ and $\mathrm{t}$ value (-30.429), and then return on equity (ROE) also has statistically significance difference with the P-value $\leq \alpha(0.016<0.05)$ and t-value (39.717). In other words, it has strong evidence that the decline in oil and gas production affect the changes in financial performance. It is in line with the study conducted by Purwanegara et al., (25). However, we reject cash ratio because $\mathrm{P}$ value $>\alpha(0.352>0.05)$ and t-value (-1.623). Because of this, we can conclude that the changes in total equity and total asset (TETA) and return on investment (ROI) are not likely due to the changes in independent variables (IV) with the p-value $(0.603>0.05) t$-value $(-7.19)$ and $p$-value $(0.109>0.05) t$-value ($5.806)$ respectively. In addition, the value of investment turnover, total asset turnover, and collection period are more than $\alpha(0.05)$. Therefore, we reject the hypothesis.

Table 3: The Variables

\begin{tabular}{|c|c|}
\hline \multicolumn{2}{|c|}{ 1. $\quad$ Profitability Ratio } \\
\hline \multirow[t]{2}{*}{$\begin{array}{l}\text { Return on } \\
\text { Equity }\end{array}$} & $\begin{array}{l}\text { Return on Equity = (Net Income/Shareholders' Equity) } \\
\text { x } 100 \%\end{array}$ \\
\hline & $\begin{array}{l}\text { ROE indicates the bank's profitability and growth po- } \\
\text { tential. }\end{array}$ \\
\hline \multirow[t]{2}{*}{$\begin{array}{l}\text { Return on } \\
\text { Investment }\end{array}$} & $\begin{array}{l}\text { Return on Investment }=((\text { total revenue }- \text { total } \\
\text { cost }) / \text { total cost }) \times 100 \%\end{array}$ \\
\hline & $\begin{array}{l}\text { ROI show the ability of the company to measure the } \\
\text { income generated on investment relative to the amount } \\
\text { of money invested. }\end{array}$ \\
\hline \multicolumn{2}{|c|}{ 2. Liquidity Ratio } \\
\hline \multirow[t]{2}{*}{ Cash ratio } & $\begin{array}{l}\text { Cash Ratio = }(\text { Cash }+ \text { cash equivalents/Current Liabili- } \\
\text { ties }) \times 100 \%\end{array}$ \\
\hline & $\begin{array}{l}\text { Cash ratio measures the liquidity of the company to } \\
\text { pay the current liabilities with only cash and cash } \\
\text { equivalents. If the cash ratio above } 1 \text {, it means that } \\
\text { company has the ability to pay its current liabilities } \\
\text { with only cash and cash equivalents. If the cash ratio } \\
\text { below } 1 \text {, the company needs more than cash and cash } \\
\text { equivalents to pay its current liabilities. }\end{array}$ \\
\hline \multirow[t]{2}{*}{ Current ratio } & $\begin{array}{l}\text { Current ratio }=(\text { Current Asset/Current Liabilities }) \mathrm{x} \\
100 \%\end{array}$ \\
\hline & The current ratio measures the company ability to pay \\
\hline
\end{tabular}




\begin{tabular}{|c|c|}
\hline & $\begin{array}{l}\text { it's short-term and long-term liabilities using their } \\
\text { short-term assets. }\end{array}$ \\
\hline \multirow[t]{2}{*}{$\begin{array}{l}\text { Collection } \\
\text { period }\end{array}$} & $\begin{array}{l}\text { Collection Period }=\text { (Average Accounts Receiva- } \\
\text { bles/Sales Revenue) x } 365 \text { days }\end{array}$ \\
\hline & $\begin{array}{l}\text { Collection period is a good indicator to measure the } \\
\text { problem of the company to collect a debt from cus- } \\
\text { tomers. If the companies have high collection period, } \\
\text { they should communicate with their customers regard- } \\
\text { ing their debts. }\end{array}$ \\
\hline \multicolumn{2}{|c|}{ 3. Activity Ratio } \\
\hline \multirow[t]{2}{*}{$\begin{array}{l}\text { Inventory } \\
\text { Turnover }\end{array}$} & $\begin{array}{l}\text { Inventory Turnover }=\text { Cost of goods sold/Average } \\
\text { Inventory }\end{array}$ \\
\hline & $\begin{array}{l}\text { Inventory turnover describes how many times the } \\
\text { inventory is sold or replaced by the company. If the } \\
\text { ratio is high, it indicates that the inventory level is } \\
\text { inadequate. If the ratio is low, it indicates that the } \\
\text { company is overstocking and deficiencies in the } \\
\text { marketing effort. }\end{array}$ \\
\hline \multirow[t]{2}{*}{$\begin{array}{l}\text { Total Asset } \\
\text { Turn Over }\end{array}$} & $\begin{array}{l}\text { Total Asset Turn Over }=(\text { Revenue/Capital Employed }) \\
\text { x } 100 \%\end{array}$ \\
\hline & $\begin{array}{l}\text { TATO ratio indicates the company ability to generate } \\
\text { revenue from deploying its asset. A Higher ratio } \\
\text { indicates that company using its assets more efficient- } \\
\text { ly and lower ratio indicate that company is using its } \\
\text { asset deficiently. }\end{array}$ \\
\hline \multicolumn{2}{|c|}{ 4. Solvency Ratio } \\
\hline \multirow[t]{2}{*}{$\begin{array}{l}\text { Total Equity to } \\
\text { Total Asset }\end{array}$} & $\begin{array}{l}\text { Total equity to total asset }=(\text { Total equity/Total asset }) \mathrm{x} \\
100 \%\end{array}$ \\
\hline & $\begin{array}{l}\text { It is a good indicator to measure the financial health of } \\
\text { the company. Equity to asset ratio measures the per- } \\
\text { centage of company's asset owned by investors and } \\
\text { the leverage level of the company with its debt. }\end{array}$ \\
\hline
\end{tabular}

Table 4: Paired Sample t-Test

\begin{tabular}{|c|c|c|c|c|c|}
\hline Description & Period & Means & \begin{tabular}{c|} 
Std. \\
Deviation
\end{tabular} & \begin{tabular}{|c|} 
Paired \\
sample t-test
\end{tabular} & Decision \\
\hline \multirow{2}{*}{ Cash Ratio } & Before & 29.6900 & 3.26683 & \multirow[b]{2}{*}{0.352} & \multirow{2}{*}{$\begin{array}{c}\text { Reject the first } \\
\text { hypothesis }\end{array}$} \\
\hline & After & 34.6400 & 7.58018 & & \\
\hline \multirow{2}{*}{ Current Ratio } & Before & \begin{tabular}{|l|}
147.8950 \\
\end{tabular} & 13.86636 & & \multirow{2}{*}{$\begin{array}{l}\text { Accept the second } \\
\text { hypothesis }\end{array}$} \\
\hline & \begin{tabular}{|l|} 
After \\
\end{tabular} & \begin{tabular}{|l|}
158.5450 \\
\end{tabular} & 13.37139 & 0.021 & \\
\hline \multirow{2}{*}{ TETA } & Before & \begin{tabular}{|l|}
37.5950 \\
\end{tabular} & 0.61518 & & \multirow{2}{*}{$\begin{array}{l}\text { Reject the third } \\
\text { hypothesis }\end{array}$} \\
\hline & \begin{tabular}{|l|} 
After \\
\end{tabular} & 39.9450 & 4.0093 & 0.603 & \\
\hline \multirow{2}{*}{ ROE } & Before & 18.1550 & 0.06364 & & \multirow{2}{*}{$\begin{array}{l}\text { Accept the fourth } \\
\text { hypothesis }\end{array}$} \\
\hline & \begin{tabular}{|l|} 
After \\
\end{tabular} & 7.6300 & 0.31113 & 0.016 & \\
\hline \multirow{2}{*}{ ROI } & Before & 15.5800 & 1.40007 & & \multirow{2}{*}{$\begin{array}{c}\text { Reject the fifth } \\
\text { hypothesis }\end{array}$} \\
\hline & After & 24.7250 & 0.82731 & 0.109 & \\
\hline \multirow{2}{*}{ ITO } & Before & 44.4100 & 2.80014 & & \multirow{2}{*}{$\begin{array}{c}\text { Reject the sixth } \\
\text { hypothesis }\end{array}$} \\
\hline & After & \begin{tabular}{|l|}
38.0600 \\
\end{tabular} & 1.45664 & 0.095 & \\
\hline \multirow{2}{*}{ TATO } & Before & \begin{tabular}{|l|}
231.4950 \\
\end{tabular} & 22.6062 & & \multirow{2}{*}{$\begin{array}{l}\text { Reject the seventh } \\
\text { hypothesis }\end{array}$} \\
\hline & \begin{tabular}{|l|} 
After \\
\end{tabular} & \begin{tabular}{|l|}
145.0250 \\
\end{tabular} & 37.95042 & 0.079 & \\
\hline \multirow{2}{*}{$\mathrm{CP}$} & Before & \begin{tabular}{|l|}
19.6400 \\
\end{tabular} & 0.45255 & & \multirow{2}{*}{$\begin{array}{c}\text { Reject the eight } \\
\text { hypothesis }\end{array}$} \\
\hline & After & 20.0850 & 3.06177 & 0.849 & \\
\hline
\end{tabular}

\section{Limitation}

This study has expanded the literature about financial performance in the real working world. In near future, it is suggested to carry out research with many companies from oil and gas industry to get more generalizes result. Since the focus is on one industry, it is worth to explore it on a wider scale and find out if different company yields the same result. In addition, the study only focuses on financial aspects. It is suggested to measure the financial performance of SEOs in other aspects such as operational and administration.

\section{Conclusion and Recommendation}

The purpose of this research is to measure the financial performance of Oil and Gas Company in Indonesia and to examine the significance differences between financial performance before the decline in oil and gas production $(2011$ - 2012) and after the decline in oil and gas production (2014-2015). The research found that the financial performance of PT. PERTAMINA for five years period is good, although there was a decline in the production which forced the government to import more oil. In addition, two ratios have different significance such as current ratio and return on equity in the period of before and after the decline in oil and gas production. Manager in Oil and Gas Company should consider these factors when analyzing the strategy and decision. This research also found that other ratios have insignificant differences on financial performance in the period of before and after the decline in oil and gas production in Indonesia. They are cash ratio, total equity to total asset, return on investment, investment turnover, collection period, and total asset turnover. This research has extent the knowledge in the theory of financial ratio analysis from oil and gas industry. This is also beneficial for the academicians and student to understand the financial ratio and help them to apply it into real working life. In addition, this study gives huge contribution for managers before investor making a decision.

\section{References}

[1] Frederer J. Oil Price Volatility and Macroeconomy: A solution to the asymmetry Puzzle. Journal of Macroeconomics. 1996;18(1):126.

[2] Anzuini A, Lombardi MJ, Pagano P. The impact of monetary policy shocks on commodity prices. 2012 .

[3] Regnier E. Oil and energy price volatility. Energy Economics. 2007;29(3):405-27.

[4] Belke A, Orth W, Setzer R. Liquidity and the dynamic pattern of asset price adjustment: A global view. Journal of Banking \& Finance. 2010;34(8):1933-45.

[5] Ratti RA, Vespignani JL. Why are crude oil prices high when global activity is weak? Economics Letters. 2013;121(1):133-6.

[6] Rohimat I, Sutarman AP. ANALISIS PENGARUH COSTUMER RELATIONSHIP MARKETING TERHADAP SISTEM DISTRIBUSI LPG 3KG (Studi Kasus pada Kecamatan Cisitu dan Wado Kab. Sumedang): UNPAS; 2016.

[7] Chong ZR, Yang SHB, Babu P, Linga P, Li X-S. Review of natural gas hydrates as an energy resource: Prospects and challenges. Applied Energy. 2016;162:1633-52.

[8] Reuters T. Thomson Reuters 2016 Know Your Customer Surveys Reveal Escalating Costs and Complexity. Thomson Reuters. 2016;9.

[9] Frecka TJ, Lee CF. Generalized financial ratio adjustment processes and their implications. Journal of Accounting Research. 1983:308-16

[10] McMahon RG, Davies LG. Financial reporting and analysis practices in small enterprises: their association with growth rate and financial performance. Journal of Small Business Management. 1994;32(1):9.

[11] Voulgaris F, Doumpos M, Zopounidis C. On the evaluation of Greek industrial SME's performance via multicriteria analysis of financial ratios. Small business economics. 2000;15(2):127-36.

[12] Black D, Van Der Westhuizen J. The allure of global games for'semi-peripheral'polities and spaces: a research agenda. Third world quarterly. 2004;25(7):1195-214.

[13] O'DONNELL C, Van Der Westhuizen G. Regional comparisons of banking performance in South Africa. South African Journal of Economics. 2002;70(3):224-40.

[14] Cooper PW. Survey BisnisKeluarga 2014. 2014.

[15] Charliepaul CK, Megaladevi K, Coimbatore C, editors. CONTROVERSY TREND DETECTION IN SOCIAL MEDIA. ideas; 2015.

[16] Waddock SA, Graves SB. The corporate social performancefinancial performance link. Strategic management journal. 1997;18(4):303-19.

[17] Cochran PL, Wood RA. Corporate social responsibility and financial performance. Academy of management Journal. 1984;27(1):42-56.

[18] Alexander GJ, Buchholz RA. Corporate social responsibility and stock market performance. Academy of Management journal. 1978;21(3):479-86

[19] Vance SC. Are socially responsible corporations good investment risks. Management review. 1975;64(8):19-24.

[20] McGuire JB, Sundgren A, Schneeweis T. Corporate social responsibility and firm financial performance. Academy of management Journal. 1988;31(4):854-72. 
[21] McGuire J, Schneeweis T, Hill J. An analysis of alternative measures of strategic performance. Advances in strategic management. 1986;4(2):1986.

[22] Halkos GE, Salamouris DS. Efficiency measurement of the Greek commercial banks with the use of financial ratios: a data envelopment analysis approach. Management accounting research. 2004;15(2):201-24.

[23] Tarawneh M. A comparison of financial performance in the banking sector: Some evidence from Omani commercial banks. International Research Journal of Finance and Economics. 2006;3(3):101-12.

[24] Iskakov S, Yilmaz N. Performance Evaluation Of Major Integrated Oil \& Gas Companies. International Journal of Economics, Commerce and Management. 2015;3(6):332-61.

[25] Purwanegara M, Apriningsih A, Andika F. Snapshot on Indonesia regulation in mobile internet banking users attitudes. ProcediaSocial and Behavioral Sciences. 2014;115:147-55.

[26] McNichols CW, Zimmerer TW. Situational ethics: An empirical study of differentiators of student attitudes. Journal of Business Ethics. 1985;4(3):175-80.

[27] Taiwo AS. The influence of work environment on workers productivity: A case of selected oil and gas industry in Lagos, Nigeria. African Journal of Business Management. 2010;4(3):299 307. 